\title{
INFLUENCE OF WEED REMOVAL AND INFESTATION PERIODS ON MAIN INSECTS INFESTING COMMON BEAN AND THEIR NATURAL ENEMIES AND PRODACTIVITY AT SOHAG GOVERNORATE
}

\author{
ESMAT A. EL-SOLIMANY ${ }^{1}$ and ABD-ELAAL. M. ABD-EL-KAREEM ${ }^{2}$
}

1. Plant Protection Research Institute, ARC, Dokki, Giza, Egypt.

2. Weed Central Laboratory, ARC, Giza, Egypt.

(Manuscript received 12 November 2017)

\begin{abstract}
$\mathrm{T}$ wo field experiments were conducted at the farm of Shandweel Agricultural Research Station, Sohag Governorate during seasons of 2016 and 2017 in summer plantation to investigate the effect of weed removal and infestation periods on major insect pests, their associated predators and productivity of common bean. Eight weed removal and infestation periods were studied in complete randomized block design. In the plots of weedfree, the weed removed for 3, 6, 9 and 12 weeks after emergence, then weeds were left to the end of growing season. For weedinfested plots, the weed were left to compete with the crop for 3 , 6, 9 and 12 weeks after emergence, and then removed to the end of growing season. Data revealed that the weeding systems affected significantly the populations of Bemisia tabaci (Genn.), Empoasca decipiens (Paoli), Aphis craccivora Koch., Thrips tabaci Lind., Coccinella undecimpunctata L. and Chrysoperla carnea (Steph.) in both seasons of the study. While, no significant effect was found for Liriomyza trifolii Burg. in both seasons. It could be included that $B$. tabaci infestation increased with decreasing weeding frequency. In contrast, E. decipiens and A. craccivora infestation decreased with decreasing weeding frequency. $C$. undecimpunctata and Ch. carnea increased in weedy common bean plots than free plots. Fresh weight and dry matter of total annual weeds reduced significantly by increased weed free period, but the previous traits increasing by increasing weed competition period. In contrast, 100 seeds weight and seed yield per feddan, the yield increased significantly by increasing weed free period, but decreased by increasing weed competition period.

Key words: Phaseolus vulgaris, Weed free, Weed infestation, Pests, Predators.
\end{abstract}

\section{INTRODUCTION}

Common bean, Phaseolus vulgaris L. is one of the most important legumanceous vegetable crops in Egypt. It is cultivated under different plantations for local and exportation, consumed as green pods and/ or dry seeds. It is a good source of protein content, energy and provides folic acid, dietary fiber and complex carbohydrates. In Sohag, common bean is liable to be attacked by many insects cause economic losses regarding the quantity and the quality of the crop yield such as $B$. tabaci, E. decipiens, A. craccivora, T. tabaci and L. trifolii (El-Solimany, 2008). 
Weeds control is one of the most important agricultural practices. Weeds can have both positive and negative effects on crop productivity. The negative way appear through competition with main crop for necessary elements of growth such as light, water and nutrients, especially in the early stages, also, they act as alternative hosts to insect pests and diseases. Jahanbakhshi and Saeedipour (2015) revealed the sensitivity of $P$. vulgaris in competition with weeds.

However, weeds indirectly affect crops via their influence on beneficial insects (Capinera, 2005). Several researchers have pointed out the important role of weeds in integrated pest management, Buckelew et al. (2000) showed that weed management systems can affect insect populations in soybean. Pobożniak (2003) reported that aphids population decreases with the lower weeding frequency. Gill et al. (2010) suggested that lesser corn stalk borer (Elasmopalpus lignosellus Zeller) attack is reduced by mulches or weeds around common bean plants. Takim and Uddin (2010) stated that the insect population influenced by weeding regime on cowpea. Also, the relationships between some insect pests and their associated predators on weeds border of the sugar beet and cotton fields were studied by Msebah and El-Husseini (2009). So, the present work aimed to evaluate the effect of weed removal periods on the abundance of main insect pests and their associated predatory insects as well as weed infestation on common bean fields.

\section{MATERIALS AND METHODS}

Experimental design: Two field experiments were conducted at the farm of Shandweel Agricultural Research Station, Sohag Governorate in clay soil during 2016 and 2017 seasons. Each experiment included eight weed removal and infestation periods treatments in complete randomized block design in three replicates and cultivated with common bean seeds (Nebraska) on $1^{\text {st }}$ March. Each plot was consisted of 6 rows of $3.5 \mathrm{~m}$. long and $70 \mathrm{~cm}$ apart. Three seeds/ hill were planted in $20 \mathrm{~cm}$ between hills, then seedlings were thinned to two plants/hill after two weeks from planting. The normal agricultural practices were performed and no pesticides were used.

Treatments: The treatments were the four weed-free and four weed-infested periods. In the plots of weed-free, the weeds were removed for 3, 6, 9 and 12 weeks after emergence, then were left leaved until the end of two growing seasons. For weed-infested treatments, the weed left to compete with the crop for 3, 6, 9 and 12 weeks after emergence, and then removed to the end of growing season. The weed removals were done by hand pulling. 
Sampling methods: Samples were started after plant emergence, continued at weekly intervals till harvesting (from $14^{\text {th }}$ March to $30^{\text {th }}$ May). Sample consisted of 10 trifoliates were randomly chosen from three levels, i.e., lower, middle and upper of common bean plants. Aphid, nymphs of leafhopper, whitefly and mines due to leafminers, also predator larvae were counted. Concerning leafhopper and whitefly adults and thrips, 10 randomly trifoliates were examined in the field and the numbers of leafhopper and whitefly were recorded. In respect of the associated predator's adults, sample of 10 plants were examined weekly and these predators were counted by the direct count method in the field.

Weeds: To determine the effect of weed removal and infestation periods on weed dry weight accumulation, weeds were sampled in one quadrate $(1.0 \mathrm{~m} \times 1.0 \mathrm{~m})$ per plot at the end of the growing season. Weeds were hand pulling at the soil level and dried at $75^{\circ} \mathrm{C}$ to a constant weight. The fresh and dry weight was recorded. The weeds accompanied with common bean crop were listed in Table (1).

Table 1. Scientific name, English name and Family for weeds accompanied common bean crop in the experimental site.

\begin{tabular}{|c|l|l|l|}
\hline Weeds type & \multicolumn{1}{|c|}{ Scientific name } & \multicolumn{1}{c|}{ English name } & \multicolumn{1}{c|}{ Family } \\
\hline \multirow{4}{*}{$\begin{array}{c}\text { Broad-leaved } \\
\text { weeds }\end{array}$} & Amaranthus retroflexus L. & Pig weed & Amaranthaceae \\
\cline { 2 - 4 } & Ipomea eriocarpa L. & Morning glory & Convolvulaceae \\
\cline { 2 - 4 } & Tribulus terrestris L. & Malta cross & Urticaeae \\
\cline { 2 - 4 } & Portulaca oleracea L. & Common purslane & Portulacaceae \\
\cline { 2 - 4 } & Daturastramomium L. & Jimsonweed & Solancaceae \\
\cline { 2 - 4 } & Xanthium spinosum L. & Cocklebar & Asteraceae \\
\hline Grassy weeds & Echinocholacolonum L. & Jungle rice & Poaceae \\
\hline
\end{tabular}

Yield: At harvest, pods were air dried, threshed and 100 seed weight determined as grams. The harvested area $\left(\mathrm{m}^{2}\right)$ from each plot was air dried and threshed in bulk, then weighted and the total grain yield ( $\mathrm{kg} / \mathrm{fed}$.) was calculated.

Data analysis: Data obtained were analyzed as complete randomized block design. Means values were distinguished using the Duncan Multiple Range Test according to Snedecor (1956).

According to Singh et al. (1996), the relationship between crop yields ( $y$ ) and duration of weed-free or weed competition period $(x)$ by either with liner function: $y=$ $a+b x$ where the parameters $y=$ expected yield, $a$ and $b$ represent intercept and slope of regression of yield on the duration, respectively, or by the quadratic function: $y=a+b x+c x^{2}$ where the parameters $b$ and $c$ represent intercept and slope of regression of yield on the duration, $y=a+b x$ and a logistic function: $y=A+C((1$ $+e-B(x-M))$ where $x$ is the duration of weed-competition period, parameter $M$ is the point of inflection of the logistic curve, $b$ shape parameter, $A$ or $A+C$ is asymptotic 
480 INFLUENCE OF WEED REMOVAL AND INFESTATION PERIODS ON MAIN INSECTS INFESTING COMMON BEAN AND THEIR NATURAL ENEMIES AND PRODACTIVITY AT SOHAG GOVERNORATE

yield depending on whether $B$ is negative or positive and $C$ is twice the difference of yield at the point of inflection and asymptotic yield.

\section{RESULTS AND DISCUSSION}

\section{1- Effect of weed removal and infestation periods on the main insect pests infesting common bean:}

\section{1- B. tabaci:}

Data presented in Table (2) showed that B. tabaci adult number significantly influenced by weed removal periods in both seasons. The highest mean number of whitefly adult was obtained from weed infestation for 12 WAE (weeks after emergence) with 10.28 and 8.03 adults/ 10 trifoliates in both seasons, respectively, with insignificant differences with weed free for 3 WAE in both seasons, and weed infestation for 9 WAE in 2017 season. While the lowest mean number was recorded in weed free for 12 WAE with 6.11 and 5.00 adults/ 10 trifoliates in both seasons, respectively, by insignificant differences with weed free for 6 WAE and 9 WAE and weed infestation for 3 WAE in both seasons.

From the same data, the number of whitefly nymphs affected significantly by weed removal periods in both seasons of the study. The treatments can arranged in two significantly groups in both seasons. The highest was consisted of weed infestation for 9 and 12 WAE and weed free for 3 WAE with 150.86, 165.42 and 142.33 nymphs/ 10 trifoliates, respectively, in 2016 season, and 123.17, 126.11 and 114.50 nymphs/ 10 trifoliates, respectively, in 2017 season. While the lowest one contained weed free for 6,9 and 12 WAE and weed infestation for 3 and 6 WAE with 105.00, 93.64, 88.00, 102.92 and 106.94 nymphs/ 10 trifoliates, respectively, in 2016 season, and $85.3178 .86,76.61,92.11$ and 88.31 nymphs/ 10 trifoliates, respectively, in 2017 season.

It could be that whitefly adults and nymphs infestation increased with decreasing weeding frequency. These findings were in harmony with results of Lanjar and Sahito (2007) who reported that complete eradication of weed reduced the activity of whitefly in okra field and Solangi et al. (2016) who reported that weeding in tomato field discourages the population buildup of whitefly on tomato crop. 
Table 2. Influence of weeding regime on certain insect pests infesting common bean plants, 2016 and 2017 seasons, Sohag Governorate.

\begin{tabular}{|c|c|c|c|c|c|c|c|c|c|c|c|c|}
\hline \multirow{4}{*}{$\begin{array}{l}\text { Weed removal or infestation } \\
\text { periods from emergence }\end{array}$} & \multicolumn{12}{|c|}{ Mean No./ 10 trifoliates } \\
\hline & \multicolumn{4}{|c|}{ B. tabaci } & \multirow{2}{*}{\multicolumn{2}{|c|}{ E, decipiens }} & \multirow{2}{*}{\multicolumn{2}{|c|}{ A. craccivora }} & \multirow{2}{*}{\multicolumn{2}{|c|}{ T. tabaci }} & \multirow{2}{*}{\multicolumn{2}{|c|}{ L. trifolii }} \\
\hline & \multicolumn{2}{|c|}{ Adults } & \multicolumn{2}{|c|}{ Nymphs } & & & & & & & & \\
\hline & 2016 season & 2017 season & $\begin{array}{l}2016 \\
\text { season }\end{array}$ & 2017 season & 2016 season & 2017 season & 2016 season & 2017 season & 2016 season & 2017 season & 2016 season & 2017 season \\
\hline Weed free for $3 W_{A E}^{*}$ & $9.03 \mathrm{ab}^{* *}$ & $7.08 \mathrm{abc}$ & $142.33 \mathrm{a}$ & 114.50 a & $25.08 \mathrm{~b}$ & $18.17 \mathrm{c}$ & $45.86 \mathrm{~cd}$ & $36.22 \mathrm{c}$ & $4.31 \mathrm{bc}$ & $3.89 \mathrm{bc}$ & $8.33 \mathrm{a}$ & $7.14 \mathrm{a}$ \\
\hline Weed free for 6 WAE & $7.17 \mathrm{~cd}$ & 5.89 cde & $105.00 \mathrm{~b}$ & $85.31 \mathbf{b}$ & $25.28 \mathrm{~b}$ & 19.81 bc & $49.39 \mathrm{bcd}$ & $37.08 \mathrm{c}$ & $4.31 \mathrm{bc}$ & $5.78 \mathrm{a}$ & $9.89 \mathrm{a}$ & $5.86 \mathrm{a}$ \\
\hline Weed free for 9 WAE & $6.42 \mathrm{~d}$ & $5.28 \mathrm{de}$ & $93.64 b$ & $78.86 \mathrm{~b}$ & 27.28 a & 22.89 ab & $53.72 \mathrm{~b}$ & 37.64 bc & $3.83 \mathrm{c}$ & $4.69 \mathrm{ab}$ & $9.58 \mathrm{a}$ & $6.47 \mathrm{a}$ \\
\hline Weed free for 12 WAE & $6.11 \mathrm{~d}$ & $5.00 \mathrm{e}$ & $88.00 \mathrm{~b}$ & $76.61 \mathrm{~b}$ & $28.44 a$ & $24.53 \mathrm{a}$ & $60.22 \mathrm{a}$ & $46.53 \mathrm{a}$ & $4.47 \mathrm{abc}$ & $2.83 \mathrm{c}$ & $7.94 \mathrm{a}$ & $7.83 \mathrm{a}$ \\
\hline Weed infestation for 3 WAE & $6.19 \mathrm{~d}$ & $6.19 \mathrm{bcde}$ & $102.92 \mathrm{~b}$ & $92.11 \mathrm{~b}$ & $28.03 \mathrm{a}$ & 22.72 ab & $52.56 \mathrm{~b}$ & $45.89 \mathrm{a}$ & $8.17 \mathrm{ab}$ & $4.83 a b$ & $8.53 \mathrm{a}$ & $7.36 \mathrm{a}$ \\
\hline Weed infestation for 6 WAE & $8.06 \mathrm{bc}$ & $6.47 \mathrm{bcd}$ & $106.94 b$ & $88.31 \mathrm{~b}$ & $25.17 \mathrm{~b}$ & $19.19 \mathrm{c}$ & $51.83 \mathrm{bc}$ & 45.19 ab & $5.81 \mathrm{abc}$ & 4.92 ab & $7.97 \mathrm{a}$ & $6.72 a$ \\
\hline Weed infestation for 9 WAE & $\begin{array}{c}8.28 \\
b c\end{array}$ & $\begin{array}{c}7.39 \\
a b\end{array}$ & $\begin{array}{c}150.86 \\
\mathrm{a}\end{array}$ & $\begin{array}{c}123.17 \\
\mathbf{a}\end{array}$ & $23.53 \mathrm{c}$ & $16.92 \mathrm{c}$ & $45.56 \mathrm{~d}$ & $43.14 a b c$ & $\begin{array}{l}6.33 \\
a b c\end{array}$ & $\begin{array}{c}5.03 \\
a b\end{array}$ & $\begin{array}{c}8.28 \\
a\end{array}$ & $\begin{array}{c}6.31 \\
a\end{array}$ \\
\hline Weed infestation for 12 WAE & $\begin{array}{c}10.28 \\
\mathrm{a}\end{array}$ & $\begin{array}{c}8.03 \\
a\end{array}$ & $\begin{array}{c}165.42 \\
\mathrm{a}\end{array}$ & $\begin{array}{c}126.11 \\
\text { a }\end{array}$ & $22.08 \mathrm{c}$ & $16.75 \mathrm{c}$ & $43.89 \mathrm{~d}$ & $42.11 \mathrm{abc}$ & $\begin{array}{c}8.31 \\
\mathbf{a}\end{array}$ & $\begin{array}{l}4.17 \\
\text { bc }\end{array}$ & $\begin{array}{c}9.83 \\
\text { a }\end{array}$ & $\begin{array}{c}7.11 \\
a\end{array}$ \\
\hline
\end{tabular}

$*$ WAE $=$ weeks after emergence, ${ }^{* *}$ Means within the same column followed by different letters are significantly different at $\mathrm{P}<0.05$ 
482 INFLUENCE OF WEED REMOVAL AND INFESTATION PERIODS ON MAIN INSECTS INFESTING COMMON BEAN AND THEIR NATURAL ENEMIES AND PRODACTIVITY AT SOHAG GOVERNORATE

\section{2- E. decipiens:}

It is clearly that the period of weed control in common bean fields influenced on the population of leafhopper in both seasons (Table 2). The highest mean number of leafhopper was observed in weed free for 12 WAE with 28.44 and 24.53 leafhoppers/ 10 trifoliates in both seasons, respectively, followed insignificantly by weed free for 9 WAE and weed infestation for 3 WAE in both seasons, while, the lowest mean number was observed in weed infestation for 12 WAE with 22.08 and 16.75 leafhoppers/ 10 trifoliates in both seasons, respectively, by insignificant differences with weed infestation for 9 WAE in 2016 season, and with weed free for 3 WAE and 6 WAE, weed infestation for 6 WAE and 9 WAE in 2017 season.

In general, leafhopper infestation decreased with decreasing weeding frequency. This result is in agreement with studies of Buckelew et al. (2000) who found that soybean systems with fewer weeds seemingly were preferred by potato leafhoppers. Takim and Uddin (2010) suggested that Empoasca spp. population increased when the crops experienced weed-free situation because of the influence of reduction in natural enemies in cowpea.

\section{3- A. craccivora:}

Depending on data of Table (2), it is evident that the weedy conditions gave significant differences in respect of aphid. The highest mean number of aphid was obtained in plots of weed free for 12 WAE with 60.22 and 46.53 aphids/ 10 trifoliates in both seasons, respectively, with insignificant differences with weed infestation for 3 WAE, 6 WAE, 9 WAE and 12 WAE in the second season. However, the lowest aphid numbers were found in weed infestation for 12 WAE with 43.89 aphids/ 10 trifoliates by insignificant differences with weed free for 3 WAE and 6 WAE and weed infestation for 9 WAE in 2016 season. However, in 2017 season, the lowest number was observed in weed free for 3 WAE with 36.22 aphids/ 10 trifoliates followed insignificantly by weed free for 6 WAE and 9 WAE, weed infestation for 9 WAE and 12 WAE.

Results suggested that aphid infestation decreased with decreasing weeding frequency. Similar findings were obtained in other crops, in maize, Penagos et al. (2003) found that the degree of infestation by aphids, Rhopalosiphum maidis (Fitch) was significantly greater in the absence of weeds, in red beet, Pobożniak (2003) who reported that bean aphid (Aphis fabae Scop.) population and the number of red beet plants colonized by aphid decreases with the lower weeding frequency i.e. with the greater coverage of the soil by weeds, reaching its minimum on the plots where weeds were not removed and in cowpea, Takim and Uddin (2010) who reported that weed-free situation in the cowpea ecosystem supported higher $A$. craccivora population because of the influence of groundcover on the optomotor landing response of the aphids. In contrast, Kanteh et al. (2014) noted that increased in population density of $A$. craccivora and foliage beetles are directly related to increase in weeds density in cowpea, it is may due to difference in study conditions. 


\section{4- T. tabaci:}

The effect of weeding regime on $T$. tabaci infesting common bean plants was significant under the study conditions in both seasons (Table 2). The highest and the lowest mean numbers were recorded in plots of weed infestation for 12 WAE and weed free for 9 WAE with 8.31 and 3.83 thrips/ 10 trifoliates, respectively, the rest treatments distributed between them in the first season. In the second season, the highest and the lowest mean numbers were recorded in plots of weed free for 6 WAE and 12 WAE with 5.78 and 2.83 thrips/ 10 trifoliates, respectively, the rest treatments, also, distributed between them.

\section{5- L. trifolii:}

Depending on the data in Table (2), it is suggested that the effect of weed removal periods on infestation of common bean plants by leafminers was insignificant under the study conditions in both seasons.

\section{2- Effect of weed removal and infestation periods on the associated insect predators:}

\section{1- C. unedcimpunctata:}

Number of adults and larvae of $C$. undecimpunctata varied significantly in both seasons of the study (Table 3). The highest mean number of adults was found in common bean plots of weed infestation for 12 WAE and weed free for 3 WAE with 1.19 and 1.42 adults/ 10 plants, respectively, in 2016 and 2017 seasons, respectively, with insignificant differences between them in both seasons. However, the lowest mean number was observed in plots of weed free for 12 WAE with 0.31 and 0.44 adults/ 10 plants in both seasons, respectively, by insignificant differences with weed free for 9 WAE and weed infestation for 3 WAE in 2016 season, and by weed free for 9 WAE, weed infestation for 3 WAE and 6 WAE in 2017 season.

Concerning to ladybird larvae, the highest and the lowest mean numbers of larvae were found in plots of weed free for 3 WAE and weed infestation for 6 WAE with 0.61 and 0.28 larvae/ 10 trifoliates, respectively, in 2016 season. No significant differences were found between the two treatments in side and the rest treatments on the other side. For 2017 season, the highest mean number was found in weed infestation for $12 \mathrm{WAE}, 1.00$ larvae/ 10 trifoliates, with insignificant differences with weed free for 3 WAE and weed infestation for 9 WAE, while the lowest number was recorded in weed free for $12 \mathrm{WAE}, 0.42$ larvae/ 10 trifoliates, with insignificant differences with the rest treatments except weed free for 3 WAE and weed infestation for 12 WAE.

It could be that the weeds may enhance the effect of $C$. undecimpunctata in common bean fields. These results are in agreement with Penagos et al. (2003) who indicated that the density of beneficial predatory Coleoptera increased significantly in maize plots with weeds comparing with clean plots. Also, Awadalla et al. (2016), the population of $C$. undecimpunctata was higher in weedy faba been than free-weedy one in both years of study. 
Table 3. Influence of weeding regime on C. undecimpunctata and Ch. carnea inhabiting common bean plants, 2016 and 2017 seasons, Sohag Governorate.

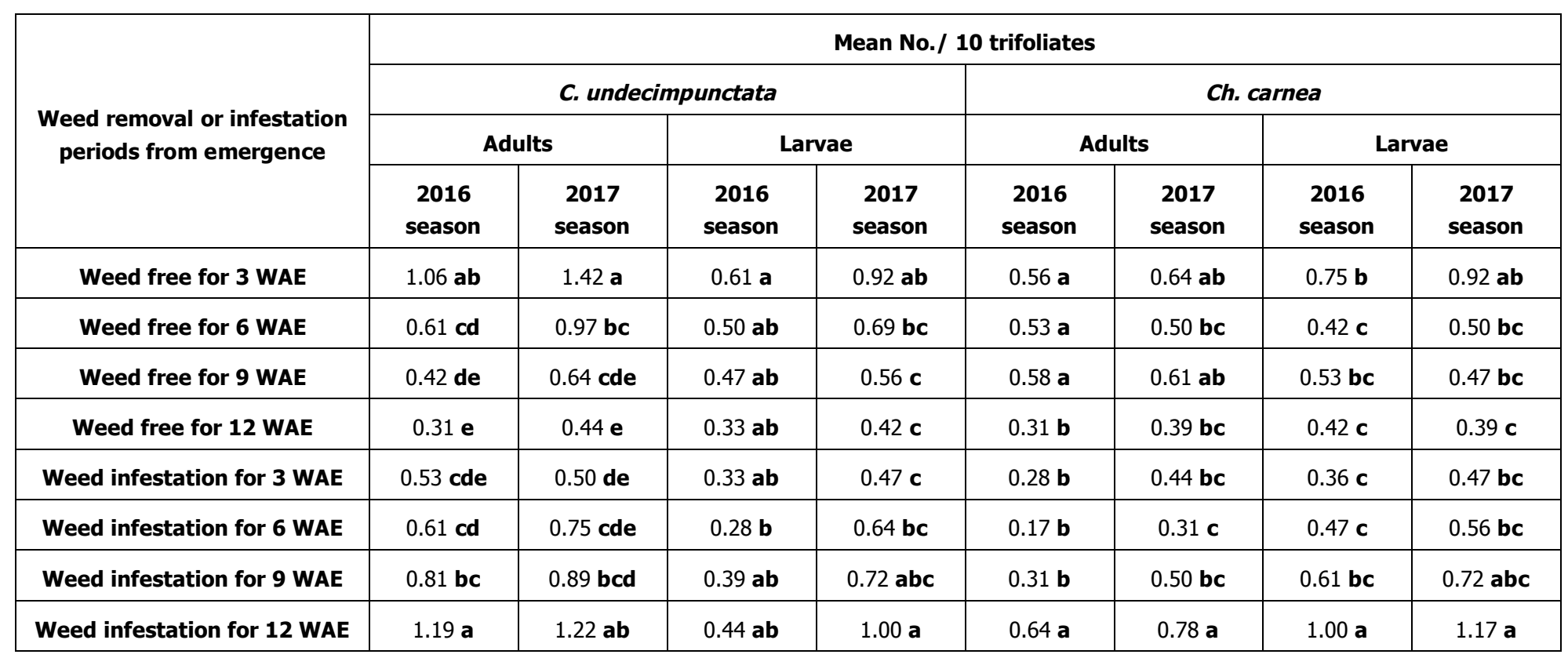

$*$ WAE $=$ weeks after emergence, $* *$ Means within the same column followed by different letters are significantly different at $\mathrm{P}<0.05$ 


\section{2- Ch. carnea:}

The population of Ch. carnea was affected significantly by weeding regime as adults and larvae in both seasons (Table 3). For adults, the treatments can arranged into two significantly groups in 2016 season. The highest one consisted of weed free for 3 WAE, 6 WAE, 9 WAE and weed infestation for 12 WAE with $0.56,0.53,0.58$ and 0.64 adults/ 10 plants, respectively, while the lowest one contained weed free for 12 WAE, weed infestation for 3 WAE, 6 WAE and 9 WAE with $0.31,0.28,0.17$ and 0.31 adults/ 10 plants, respectively. In 2017 season, the highest mean number of Ch. carnea adults was obtained in weed infestation for $12 \mathrm{WAE}, 0.78$ adults/ 10 plants, with insignificant differences with weed free for 3 WAE and 9 WAE, however, the lowest one was observed in weed infestation for 6 WAE, 0.31 adults/ 10 plants, with insignificant differences with weed free for 6 WAE and 12 WAE, weed infestation for 3 WAE and 9 WAE.

For larvae, it is clear that the highest mean number was recorded in weed infestation for 12 WAE with 1.00 and 1.17 larvae/ 10 trifoliates in both seasons, respectively, with insignificant differences with weed free for 3 WAE and weed infestation for 9 WAE in the second season. The lowest mean number of larvae was recorded in weed infestation for 3 WAE and weed free for 12 WAE in both seasons, respectively, with 0.36 and 0.39 larvae/ 10 trifoliates, respectively, comparing with weed free for 3 WAE and weed infestation for 12 WAE only in both seasons. Weeds can directly affect the abundance of predators (Al-Doghairi and Cranshaw, 2004 and Showler and Greenberg 2003). Similar results were obtained by Awadalla et al. (2016) who found that, the population of Ch. carnea was higher in weedy faba been than free-weedy one in both years of study.

\section{3- Effect of weed removal and infestation periods on weeds:}

Data in Table (4) revealed that both the fresh and dry matter were affected significantly by weeding regimes used in both growing seasons. Fresh weight of total annual weeds at the end growing seasons reduced significantly by increased weed free period, but the pervious traits increased by increasing weed 
Table 4. Influence of weeding regime on total annual weeds and common bean yield, 2016 and 2017 seasons, Sohag Governorate.

\begin{tabular}{|c|c|c|c|c|c|c|c|c|c|c|}
\hline \multirow{2}{*}{$\begin{array}{l}\text { Weed removal or } \\
\text { infestation periods from } \\
\text { emergence }\end{array}$} & \multicolumn{2}{|c|}{$\begin{array}{c}\text { Fresh weight (gram/ } \\
\qquad \mathrm{m}^{2} \text { ) }\end{array}$} & \multicolumn{2}{|c|}{$\begin{array}{l}\text { Dry matter } \\
\text { (gram/ m²) }\end{array}$} & \multicolumn{2}{|c|}{$\begin{array}{l}100 \text { seeds weight } \\
\text { (gram/ } 100 \text { seeds) }\end{array}$} & \multicolumn{2}{|c|}{$\begin{array}{l}\text { Top yield } \\
\text { (Kg/fed.) }\end{array}$} & \multicolumn{2}{|c|}{ Yield loss $\%$} \\
\hline & $\begin{array}{c}2016 \\
\text { season }\end{array}$ & $\begin{array}{c}2017 \\
\text { season }\end{array}$ & $\begin{array}{c}2016 \\
\text { season }\end{array}$ & $\begin{array}{c}2017 \\
\text { season }\end{array}$ & $\begin{array}{c}2016 \\
\text { season }\end{array}$ & $\begin{array}{c}2017 \\
\text { season }\end{array}$ & $\begin{array}{c}2016 \\
\text { season }\end{array}$ & $\begin{array}{c}2017 \\
\text { season }\end{array}$ & $\begin{array}{c}2016 \\
\text { season }\end{array}$ & $\begin{array}{c}2017 \\
\text { season }\end{array}$ \\
\hline Weed free for 3 WAE & $293.00 \mathrm{~b}$ & $245.33 b$ & $98.00 \mathrm{a}$ & $82.67 \mathrm{~b}$ & $18.00 \mathrm{de}$ & $18.77 \mathrm{~cd}$ & $313.33 \mathrm{C}$ & $\begin{array}{c}477.33 \\
\text { bc }\end{array}$ & 48.20 & 25.37 \\
\hline Weed free for 6 WAE & $155.67 \mathrm{~d}$ & $153.00 \mathrm{c}$ & $51.33 \mathrm{c}$ & $51.67 \mathrm{~d}$ & $\begin{array}{l}20.67 \\
\text { cde }\end{array}$ & $\begin{array}{l}21.07 \\
\text { bcd } \\
\end{array}$ & $\begin{array}{c}398.33 \\
\text { bc }\end{array}$ & $\begin{array}{c}482.33 \\
\text { bc }\end{array}$ & 34.15 & 24.58 \\
\hline Weed free for 9 WAE & 104.00 ef & $93.00 \mathrm{~d}$ & 34.67 de & $31.67 \mathrm{e}$ & $21.60 \mathrm{~cd}$ & $22.20 \mathrm{bc}$ & $424.00 \mathrm{~b}$ & $\begin{array}{c}540.60 \\
a b \\
\end{array}$ & 29.91 & 15.47 \\
\hline Weed free for 12 WAE & $39.67 \mathrm{~g}$ & $27.67 \mathrm{e}$ & $13.67 \mathrm{f}$ & $\begin{array}{c}9.33 \\
\mathbf{g} \\
\end{array}$ & $31.67 \mathbf{a}$ & $31.67 \mathbf{a}$ & 604.90 a & $639.57 \mathbf{a}$ & 0.00 & 0.00 \\
\hline $\begin{array}{c}\text { Weed infestation for } 3 \\
\text { WAE }\end{array}$ & $80.67 \mathrm{f}$ & $62.33 \mathrm{de}$ & 26.67 ef & $21.33 \mathrm{f}$ & $27.37 \mathrm{ab}$ & $27.00 \mathrm{ab}$ & $441.07 \mathrm{~b}$ & $\begin{array}{c}595.63 \\
\text { ab } \\
\end{array}$ & 27.08 & 6.87 \\
\hline $\begin{array}{c}\text { Weed infestation for } 6 \\
\text { WAE }\end{array}$ & $\begin{array}{c}126.67 \\
\text { de }\end{array}$ & $140.00 \mathrm{c}$ & $42.67 \mathrm{~cd}$ & $47.00 d$ & $25.30 \mathrm{bc}$ & $25.63 \mathrm{ab}$ & $\begin{array}{c}376.23 \\
\text { bc }\end{array}$ & $390.00 \mathrm{C}$ & 37.80 & 39.02 \\
\hline $\begin{array}{c}\text { Weed infestation for } 9 \\
\text { WAE }\end{array}$ & $211.67 \mathrm{c}$ & $213.00 \mathrm{~b}$ & $71.00 \mathrm{~b}$ & $71.33 \mathrm{c}$ & $\begin{array}{r}22.60 \\
b c d\end{array}$ & $22.80 \mathrm{bc}$ & $\begin{array}{c}355.07 \\
\text { bc }\end{array}$ & $372.00 \mathrm{C}$ & 41.30 & 41.84 \\
\hline $\begin{array}{c}\text { Weed infestation for } 12 \\
\text { WAE }\end{array}$ & $529.33 a$ & $433.67 a$ & $101.67 \mathrm{a}$ & 93.33 a & $15.67 \mathrm{e}$ & $15.50 \mathrm{~d}$ & $183.87 \mathrm{~d}$ & $207.33 d$ & 69.60 & 67.58 \\
\hline
\end{tabular}

$*$ WAE $=$ weeks after emergence.

** Means within the column followed by different letters are significantly different at $\mathrm{P}<0.05$

competition period. The highest fresh weight was observed in plots of weed infestation for 12 WAE with 529.33 and $433.67 \mathrm{gram} / \mathrm{m}^{2}$ in both seasons, respectively. While the lowest fresh weight was observed in plots of weed free for 12 WAE with 39.67 and $27.67 \mathrm{gram} / \mathrm{m}^{2}$ in both seasons, respectively, with insignificant deference with weed infestation for 3 WAE in the second season.

Also, dry weight of total annual weeds at the end of growing seasons reduced significantly by increased weed free period, but the pervious traits decreased by reduce weed competition period. The highest dry weight was observed in plots of weed infestation for 12 WAE with 101.67 and $93.33 \mathrm{gram} / \mathrm{m}^{2}$ in both seasons, respectively, with insignificant difference with weed free for 3 WAE in the first season. However, the lowest fresh weight was observed in plots of weed free for 12 WAE with 13.67 and $9.33 \mathrm{gram} / \mathrm{m}^{2}$ in both seasons, respectively, with insignificant deference with weed infestation for 3 WAE in the first season. Similar result was recorded by Ahmadi et al. (2007) who found that weed dry matter per unit area increased by increasing of weed infested period, they added that the whole season weed infestation produced the highest weed dry matter. The inverse is correct for weed free period. 


\section{4- Effect of weed removal and infestation periods on common bean yield:}

Data presented in Table (4) showed that 100 seeds weight significantly influenced by weed removal at different times in both seasons. The highest 100 seeds weight resulted from weed free for 12 WAE with $31.67 \mathrm{gram} / 100$ seeds in both seasons, followed insignificantly by weed infestation for 3 WAE in both seasons, and weed infestation for 6 WAE in the second season only. On the other hand, the lowest values were obtained from weed infestation for 12 WAE with 15.67 and $15.50 \mathrm{gram} /$ 100 seeds in 2016 and 2017 seasons, respectively, with insignificant differences with weed free for 3 WAE and 6 WAE in both seasons. Similar results were obtained from Mukhtar (2012).

Concerning the top yield per feddan, the yield increased significantly by increasing weed free period, but decreased by increasing weed competition period. The highest top yield was resulted from weed free for 12 WAE with 604.90 and $639.57 \mathrm{Kg} / \mathrm{fed}$. in 2016 and 2017 seasons, respectively, with insignificant differences with weed free for 9 WAE and weed infestation for 3 WAE in the 2017 season. Meanwhile, the lowest value was obtained from weed infestation for 12 WAE with 183.87 and $207.33 \mathrm{Kg} /$ fed. in 2016 and 2017 seasons, respectively. Data revealed that the highest yield loss (comparing with weed free for 12 WAE) was recorded in plots of weed infestation for 12 WAE with 69.60 and $67.58 \%$ in both seasons, respectively.

These results agreed with Ghamari and Ahmadvand (2013) who reported that the lowest dry bean yield was observed in season-long weed-infested treatment, while the maximum one was recorded in season-long weed-free treatment.

\section{5- Estimation of critical period of common bean - weed competition:}

Table (5) and Fig. (1) showed that the relationship between seed yield ( $\mathrm{Kg} / \mathrm{fed})$ of common bean and period of weed removal was high significant with linear, quadratic and logarithmic models. Depending on the value of $\mathrm{R}^{2}$, it is clear that the best model fitted to the yield of weed free and weed competition was quadratic model, because it has the highest value of $\mathrm{R}^{2}$. Therefore, the quadratic model worked well for describing the relation between seed yield of common bean and weeds under weed free and weed competition conditions. On the other hand, the lowest standard error (SE) was obtained from logistic model under weed free and weed competition conditions in both seasons. These results are in harmony with Whish et al. (2002). 
488 INFLUENCE OF WEED REMOVAL AND INFESTATION PERIODS ON MAIN INSECTS INFESTING COMMON BEAN AND THEIR NATURAL ENEMIES AND PRODACTIVITY AT SOHAG GOVERNORATE

Table 5. The $\mathrm{R}^{2}$ and SE of linear, quadratic and logarithmic models between common bean seed yield with weed free and weed infestation of 2016 and 2017 seasons.

\begin{tabular}{|c|c|c|c|c|c|c|}
\hline \multicolumn{7}{|c|}{2016 season } \\
\hline \multirow{2}{*}{ Treatments } & \multicolumn{2}{|c|}{ Linear } & \multicolumn{2}{|c|}{ Quadratic } & \multicolumn{2}{|c|}{ Logistic } \\
\hline & $\mathbf{R}^{2}$ & SE & $\mathbf{R}^{2}$ & SE & $\mathbf{R}^{2}$ & SE \\
\hline Weed free & 0.893 & 34.161 & 0.967 & 19.968 & 0.850 & 0.141 \\
\hline Weed infestation & 0.664 & 71.016 & 0.765 & 62.511 & 0.648 & 0.159 \\
\hline F value weed free & \multicolumn{2}{|c|}{$83.38^{* *}$} & \multicolumn{2}{|c|}{$132.15^{* *}$} & \multicolumn{2}{|c|}{$56.50 * *$} \\
\hline F value weed infestation & \multicolumn{2}{|c|}{$19.72 * *$} & \multicolumn{2}{|c|}{$14.68^{* *}$} & \multicolumn{2}{|c|}{$18.38^{* *}$} \\
\hline \multicolumn{7}{|c|}{ Fitted function quadratic model } \\
\hline Weed free & \multicolumn{6}{|c|}{$\hat{Y}=183.123+1.858 X-0.953 X^{2}$} \\
\hline Weed infestation & \multicolumn{6}{|c|}{$\hat{Y}=602.133-1.885 X+1.117 X^{2}$} \\
\hline \multicolumn{7}{|c|}{2017 season } \\
\hline \multirow{2}{*}{ Treatments } & \multicolumn{2}{|c|}{ Linear } & \multicolumn{2}{|c|}{ Quadratic } & \multicolumn{2}{|c|}{ Logistic } \\
\hline & $\mathbf{R}^{2}$ & SE & $\mathbf{R}^{2}$ & SE & $\mathbf{R}^{\mathbf{2}}$ & SE \\
\hline Weed free & 0.614 & 97.663 & 0.694 & 82.837 & 0.643 & 0.261 \\
\hline Weed infestation & 0.799 & 61.938 & 0.819 & 64.858 & 0.802 & 0.118 \\
\hline F value weed free & \multicolumn{2}{|c|}{$15.88^{* *}$} & \multicolumn{2}{|c|}{$13.49 * *$} & \multicolumn{2}{|c|}{$18.00 * *$} \\
\hline F value weed infestation & \multicolumn{2}{|c|}{$39.76 * *$} & \multicolumn{2}{|c|}{$18.19 * *$} & \multicolumn{2}{|c|}{$45.32 * *$} \\
\hline \multicolumn{7}{|c|}{ Fitted function quadratic model } \\
\hline Weed free & \multicolumn{6}{|c|}{$\hat{Y}=223.247+2.021 X-1.292 X^{2}$} \\
\hline Weed infestation & \multicolumn{6}{|c|}{$\hat{Y}=657.033-1.066 X+0.180 X^{2}$} \\
\hline
\end{tabular}
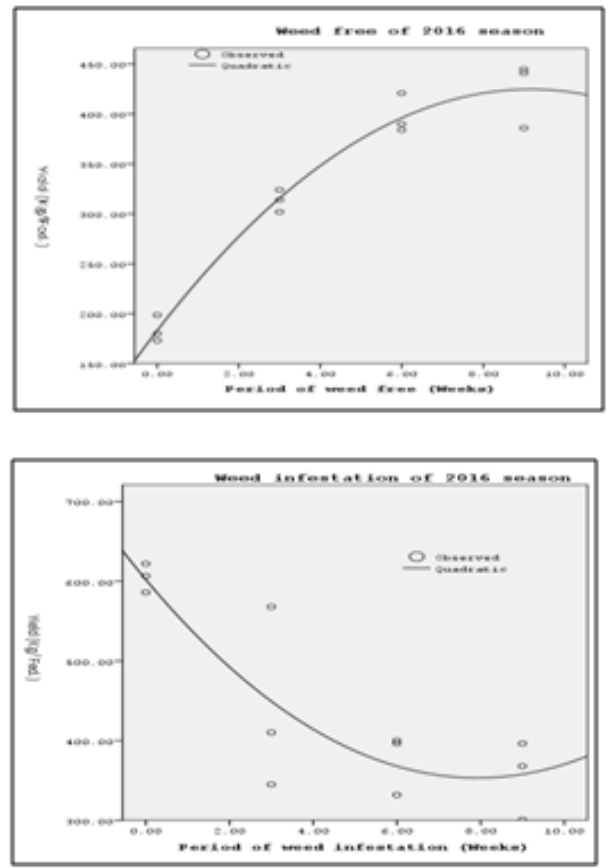
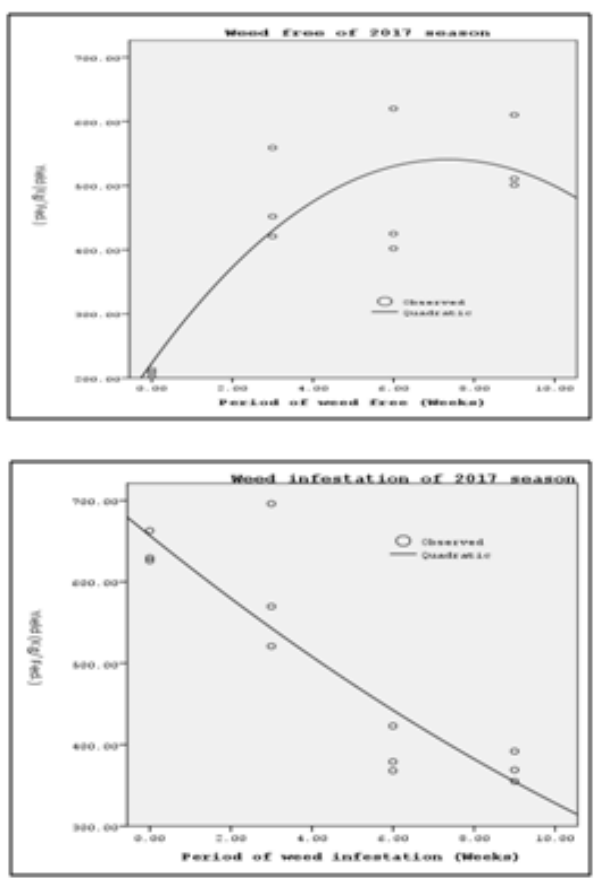

Fig. 1. The relationship between duration of weed free or weed infestation and seed yield of common bean ( $\mathrm{Kg} /$ Fed.) in 2016 and 2017 seasons. 


\section{REFERENCES}

1. Ahmadi, A.; R. M. Talarposhti; S. K. Mousavi and H. Mohammadi. 2007. Determination of the critical period of weed control in dry bean using a thermal basis. Iranian J. Weed Sci. 3(1\& 2): 21-38.

2. Al-Doghairi, M. A. and W. S. Cranshaw. 2004. The effect of interplanting of nectariferous plants on the population density and parasitism of cabbage plants. South. Entomol. 29:61-68.

3. Awadalla, S. S.; S. B. Beleh; M. H. Bayoumy and H. S. Abd El-Aty. 2016. Effect of faba bean weeds on the population of cowpea aphid Aphis craccivora (koch.) and its associated predatory insects. J. Plant Prot. and Path., Mansoura Univ., Vol.7 (6), 361- 367.

4. Buckelew, L. D.; L. P. Pedigo; H. M. Mero; M.D.K. Owen and G. L. Tylka. 2000. Effects of weed management systems on canopy insects in herbicide-resistant soybeans. J. Econ. Entomol. 93(5): 1437-1443.

5. Capinera, J. L. 2005. Relationships between insect pests and weeds: an evolutionary perspective. Weed Sci. 53(6):892-901.

6. El-Solimany, E. A. 2008. Ecological studies on the main pests and their natural enemies associated with some legume vegetables in Upper Egypt. M.Sc. Thesis, Fac. Agric. Minia Univ. pp. 185.

7. Ghamari, H. and G. Ahmadvand. 2013. Growth analysis of dry bean (Phaseolus vulgaris L.) in different weed interference situations. Not Sci Biol. 5(3): 394-399.

8. Gill, H.K.; R. McSorley; G. Goyal and S.E. Webb. 2010. Mulch as a potential management strategy for lesser corn stalk borer, Elasmopalpus lignosellus (Insecta: Lepidoptera: Pyralidae), in bush bean (Phaseolus vulgaris). Florida Entomol., 93(2):183-190.

9. Jahanbakhshi, M. and S. Saeedipour .2015. Determination of critical period of weeds control in french bean (Phaseolus vulgaris L.) in Iran. Int. J. Biosci. Vol. 6(2): 411-417.

10. Kanteh, S.M; J.E. Norman and J.S. Kamara. 2014. Effect of plant density and weeding regime on population and severity of aphids (Aphis craccivora Koch) and foliage beetles (Ootheca mutabilis Sahl) on cowpea in Sierra Leone. Intern. J. Agric. \& Forestry. 4(1): 24-33.

11. Lanjar, A. G. and H.A. Sahito. 2007. Impact of weeding on whitefly, Bemesia tabaci (Genn.) population on okra crop. Pak. J. Weed Sci. Res. 13(3-4): 209-217. 
490 INFLUENCE OF WEED REMOVAL AND INFESTATION PERIODS ON MAIN INSECTS INFESTING COMMON BEAN AND THEIR NATURAL ENEMIES AND PRODACTIVITY AT SOHAG GOVERNORATE

12. Msebah, A.H. and M.M. El-Husseini. 2009. Effect of weed borders on insect pests and their associated predators on sugar beet and cotton plant fields. Egypt. Acad. J. biolog. Sci., 2(1): 73- 80.

13. Mukhtar A. M. 2012. Critical period of weed interference in irrigated common bean (Phaseolus vulgaris. L.) in Dongola area. J. Sc. Tech 12 (3): 1-6.

14. Penagos, D. I.; R. Magallanes; J. Valle; J. Cisneros; A. M. Marti'NEZ; D. Goulson; J. W. Chapman; P. Caballero; R. D. Cave and T. Williams. 2003. Effect of weeds on insect pests of maize and their natural enemies in Southern Mexico. Intern. J. Pest Management. 49(2) 155-161.

15. Pobożniak, M. 2003. Occurrence of bean aphid (Aphis fabae Scop.) on red beet in relation to different coverage of soil by weeds. Integrated Control in Field Vegetable Crops. IOBC Bulletin 26 (3): 345-353

16. Sing, M.; M. C. Sexena; A. B. E. Abu-Irmaileh; S. A. Al-Thabbi and N. I. Haddad. (1996). Estimation of critical period of weed control. Weed Sci. 44(2): 273-283.

17. Showler, A. T. and S. M. Greenberg. 2003. Effects of weeds on selected arthropod herbivore and natural enemy populations, and on cotton growth and yield. Environ. Entomol. 32:39-50.

18. Solangi, A.; A.G. Lanjar; A. Bukero; A.R. Shah; S.A. Nahyoo and B. H. Chang. 2016. Weeding, a population suppression tool for Bemisia tabaci (Hemiptera: Aleyrodidae) on tomato crop. Sci. Int. (Lahore). 28(4): 4007-4012.

19. Snedecor, G. W. 1956. Statistical methods. Lowa State Collage Press, Ames, Iowa, U.S.A.

20. Takim, F. O. and R. O. Uddin. 2010. Effect of weed removal on insect populations and yield of cowpea [Vigna unguiculata (L) Walp]. Aust. J. Agric. Engin.. AJAE. 1(5):194-199.

21. Whish, J. P.; B. M. Sindel; R. S. Jessop and W. L. Felton. 2002. The effect of row spacing and weed density on yield loss of chekpea. Aust. J. Agric. Res. 53: 13351340. 


\title{
تأثير فترات إزالة الحشائش ومنافستها علي الحشرات الرئيسية التي تصيب

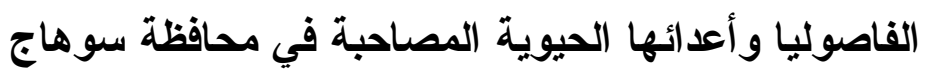

\author{
عصمت أحمد السليماني' و عبدالعال محمد عبدالكريم \\ ا ـ معهز بحوث وقاية النباتات، مركز البحوث الزراعبة، الدقى - الجيزة، مصر

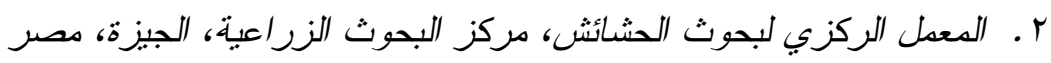

أجريت هذه الدر اسة في مزرعة محطة البحوث الزر اعية بجزيرة شــندويل فــي محافظـــة

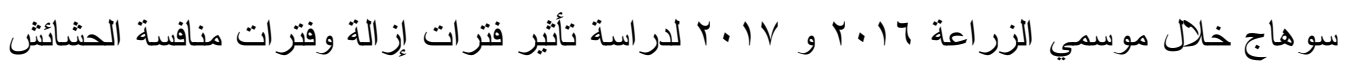
علي بعض الآفات الحشرية و المفترسات المصاحبة لها علي محصول الفاصوليا. تم استخدام ثمانيـــة

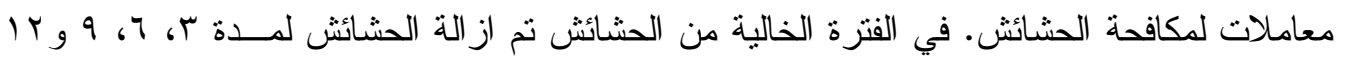
اسبوع من بداية الإنبات ثم يتم تركها لنهاية الموسم. بالنسبة لفترة منافسة الحشائش تم ترك الحشائش من

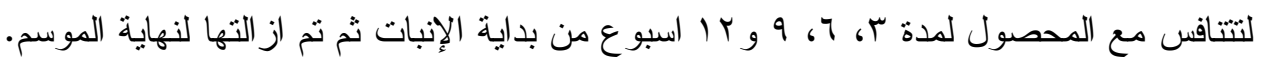

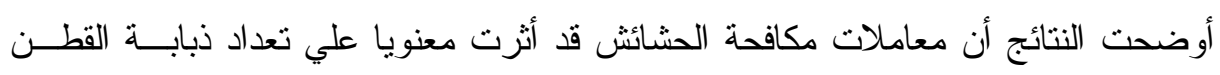

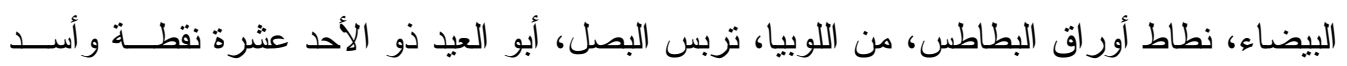

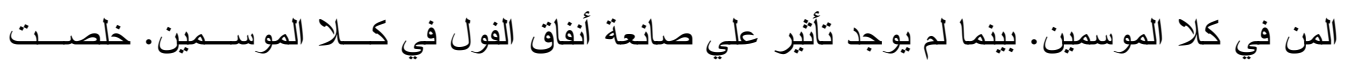

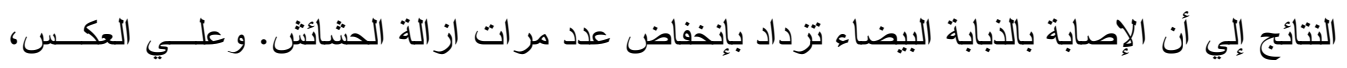
لوحظ أن الإصابة بنطاطات الأور اق ومن اللوبيا تتخفض بإنخفاض عدد مر ات الإن الة الة الحشائش. بينما تعداد أبو العيد ذو الأحد عشرة نقطة وأسد المن يزيد في قطع الفاصوليا المصابة بالحشائش عنها في القطع الخالية من الحثائش. انخفض الوزن الغض و الوزن الجاف للحشائش الكلية معنويا بزيادة الفتــرة الخاليـــة مــن

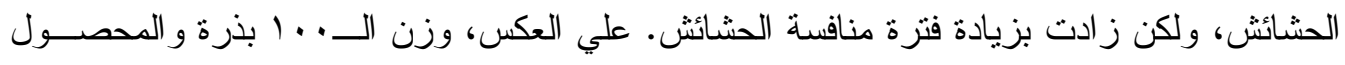
الكلي بالنسبة للفدان زادت بزيادة الفترة الخالية من الحشائش ونقصت بزيادة فترة منافسة الحشائش. 
